\title{
TRAILING THE GROWTH FROM NATIVISM TO AFRICANITY IN LUSOPHONE AFRICAN POETRY
}

\author{
Sovon Sanyal \\ Centre of Spanish, Portuguese, Italian \& Latin American Studies \\ Jawaharlal Nehru University, Delhi, India \\ sksanyal@mail.jnu.ac.in
}

\begin{abstract}
Article explored the development of African poetry, that is from nativism to be Africanity, in Lusophone African poetries. The study used library research by analysing the impact of printing press, public education, and freedom of expression emergences toward literary activities in Portuguese colonies in Africa. In this regard ethnological and historical studies on the colonies had an important role to play for the later development of nationalism among the colonised African peoples. Article's discussion concerned with describing proper literary activities in Portuguese began in the Lusophone countries of Africa, poetry characterization by the "black" and "white" presentations, added by some example of poetries. It can be concluded the problematic of colour is present in African poems in Portuguese right from its inception, The common purpose of the nineteenth century Lusophone African poets was to discover the regional cultural history and identity, which was denied to them for centuries by the foreign rulers.
\end{abstract}

Keywords: nativism, Africanity, poetry, Lusophone

\begin{abstract}
ABSTRAK
Artikel menjelaskan perkembangan puisi di Afrika, yaitu dari bentuk nativism ke bentuk Africanity, seperti yang ditunjukkan oleh puisi Afrika yang dikarang oleh penyair Lusophone. Penelitian menggunakan studi pustaka dengan cara menganalisis dampak yang ditimbulkan oleh terbitnya media cetak, adanya pembelajaran publik, dan kebebasan berekspresi yang berdampak pada kegiatan penulisan di daerah koloni Portugis di Afrika. Dalam kasus ini, bahasan etnologi dan sejarah yang terkait dengan koloni memegang peran penting bagi tumbuhnya nasionalisme di antara orang-orang di daerah koloni Afrika. Diskusi artikel menjelaskan gambaran kegiatan sastra yang benar-benar terjadi di Portugis, yang dimulai dari daerah Lusophone di Afrika. Puisi tersebut bercirikan simbol yang menggambarkan hitam dan putih, dan disertai dengan contoh beberapa puisi. Disimpulkan bahwa masalah warna kulit telah lama ditemukan di puisi Portugis sejak lama. Penyair di daerah Lusophone di Afrika membuat puisi tersebut dengan tujuan menemukan sejarah budaya regional beserta identitasnya. Hal ini telah disembunyikan bagi mereka oleh pihak penguasa.
\end{abstract}

Kata kunci: nativism, Africanity, puisi, Lusophone 


\section{INTRODUCTION}

The nineteenth century Liberal Revolution in Portugal, the Independence of Brazil in 1822, the Abolition of Slave Trade in 1811 are the main socio-political events that had a great impact on the subsequent course of history of Portugal and its colonies. With the introduction of printing press, public education, freedom of expression (in a very limited way) in the Portuguese colonies in the same century, the colonised people had some free access to European knowledge which ultimately initiated literary activities in Portuguese among them. Moreover, the abolition of Inquisition in 1812 and of Slavery in 1884 did create a congenial atmosphere for intellectual activities in the colonies. The appearance of newspapers and literary magazines in the Portuguese colonies of Africa and Asia in the nineteenth century helped to spread consciousness of national identity among the colonised. In this regard ethnological and historical studies on the colonies had an important role to play for the later development of nationalism among the colonised African peoples.

It was during this time that proper literary activities in Portuguese began in the Lusophone countries of Africa --- Angola, Mozambique, Cape Verde and São Tomé e Principe. The body of literature in Portuguese that emerged in the Lusophone countries has been divided by Manuel Ferreira (1986) into groups: "Literatura colonial" (colonial literature) and "Literatura Africana de Expressão Portuguesa” (African literature of Portuguese expression).

The narrative or poetic discourse of colonial literature is characterised by the presence of the Europeans in its very centre. The "Black" whenever he/she appears, though rarely, assumes a much degraded position. The "White", in such literatures, is depicted, though strangely, as the hero who is sacrificing himself for the good of the colonised, assuming an image of Salvador. The "Black" in general was "coisificado", i.e., he was depicted as "coisa” or an object.

In the nineteenth century the African literature of Portuguese expression emerged along with the colonial literature. This literature of Portuguese expression brought to its discourse the world of the Africans i.e., that of the "Black", the colonised and exploited people. In the beginning it was neither very realistic in its presentation nor did show the Black world in total opposition to the White one. It was a real uphill struggle for the writers to reject the colonial values which were then highly institutionalised.

\section{METHODS}

The author used library research by analysing the impact of printing press, public education, and freedom of expression emergences toward literary activities in Portuguese colonies in Africa continued by analysing the six Lusophone poems as examples, those are : A Minha Terra, Kicolá!, The Mulemba, In a Negro Dance, Negress, and I and the Passer.

\section{DISCUSSION}

In all the literatures, written in Portuguese language before the nineteenth century, the Africans were completely absent. In the works of Gil Vicente (1465?-1537), Henrique da Mota (14751545?) and Gregorio de Mattos (1636?-1697), the Black appeared only in zoomorphic forms. It was the Brazilian poet Gonçalves Crespo (1846-1883) who created for the first time literary space for the "black" as people in Portuguese literature. 
Colonization is the "negation of personality of the other". It not only exploits the colonised economically, but also substitutes the world of the oppressed or the colonised with that of the colonizer. Religion, language, dress, food habit, thought process and social values of the colonised either disappear or are transformed under colonial rule. In short, the colonised are imprisoned in the coloniser's world, resulting in cultural alienation.

Due to the inherent contradiction within itself, colonialism becomes responsible, at a certain stage of its development, for the attempt on the part of the colonised to return to their own world. The African literature of Portuguese expression emerged out of the conflict between the Portuguese and the African worlds rejecting the former and returning to the cultural roots of the later. It is thus a return journey for the denationalised people.

Manuel Ferreira has shown that there are four stages in the development of African literature in Portuguese. First, the writers appeared Europeanised in their thought process. Second, they manifested, in spite of their alienation from the local culture, rationalistic tendencies in their narrative or poetic discourse through socio-cultural and topographical descriptions, thus creating in this stage an incipient nationalism. Third, after becoming aware of their colonised condition the African writers not only liberated themselves from their alienation but also portrayed the social reality of the colonies. Fourth, with the national liberation, the writers completely freed themselves from the colonial values and began the process of reconstruction of their individuality.

Here the writer intended to trace the growth of incipient nationalism in the Lusophone poetry through "nativism" and "Africanity". By "natives" the writer meant that phenomenon which initiated the Lusophone poetry in the nineteenth century through regional consciousness. The term "Africanity" has to be taken in a very narrow sense. It is just the embryonic pan-African feeling-the feeling for the Negro race. One can observe that Africanity emerged from nativism.

The nativism in the African literature of Portuguese expression is manifested, right from its inception, in the poetic discourse through topographical and ethno-cultural descriptions of different regions of Africa. The poets reconstructed the world of the "Black" through the description of local food, dress, flora and fauna, Negro women, festivals, etc. It not only minimizes the poet's cultural alienation, but also gives him an opportunity to show his fraternity with the indigenous people.

This nativism, initiated by the nineteenth century African poets of the Lusophone countries, is the forerunner of the Africanity which is the general awareness among the writer of having a common cultural and racial identity along with the awareness of their humiliated condition. This Africanity later evolved and merged into the movement of negritude in the twentieth century.

José da Silva Maia Ferreira (1827-1881), the mestiço poet of Angola, in his poem A Minha Terra, published in his book Espontaniedade da Minha Alma (1849), made an attempt to reconstruct the exotic indigenous world through cultural ad topographical descriptions. It shows a strong nativist streak and regionalism of Romanticist vein. I quote here from the poem A Minha Terra.

"It has palm trees with bushy shadows

Where the chief of the savage tribe,

In caravan of weary people

Falls asleep eager for breeze.

In those hills runs about anxiously,

The assegai with vibrating force,

The African warrior and famous

At his feet, the prostrate panther...”

(My Land by José da Silva Maia Ferreira) 
The same regional consciousness and search for the lost cultural heritage is found in the poet's other works.

Forty years after the publication of A Minha Terra, another Angolan poet, Joaquim Cordeiro da Matta (1857-1894), celebrated his Terra Natal through the extensive use of ethno-cultural elements of clothing, food and language of the Black of his country. Cordeiro da Matta also attempted to valorise the Black women. In the process the Black/White opposition and the cultural conflict between the two races were contextualised. The incipient valorisation of the local culture made by the poet is conditioned by colonial norms. The poems Negra! and Cambuta show the nativism that was taking root in the Lusophone poetry of Africa. Let us see how it is reflected in the poem Kicolá!

"In this small town,

I saw a certain maid

Who was very beautiful,

Like a fairy, a houri and a goddess

To whom I said - Oh my dear,

I ask for a kiss, if you please;

You know well, oh my love,

I would give my life for you!"

- Nquami-ami, ngna-iame

"I don't want to, my dear Sir"

Said she without changing colour;

- Nacuto, quangadall'ami.

"I don’t believe in your love..."

(Kicolá! by Cordeiro da Matta)

Some poets in their works hark back to their childhood world. It is not merely nostalgia or longing for the days of perfect happiness of childhood, on the country, it served as a pretext for delving into the indigenous society of the pre-colonial era. In Mulemba secou, the Angolan poet Ayres de Almeida Santos (1922-1991) discovers the local African society in the remembrance of his infancy. The alienation from the ancestral culture due to the foreign domination is symbolised in the death of the Mulemba tree which was of special religious significance.

"The mulemba has dried

In the mud of the road,

Trampled

By everyone.

The leaves became

Dry, yellow

Crackling under the feet of those who passed by.

Afterwards the wind lifted them away...

Like the leaves of the mulemba

The carefree dreams of

The kids of my quarter.”

(The Mulemba has dried by Ayres de Almeida Santos)

Another literary phenomenon emerged in the Lusophone African poetry in the form of celebration of the native land. It is marked by the linguistic coexistence, i.e., the use of regional languages in texts written in Portuguese. It is found in the works of Cordeiro da Matta and his contemporary and compatriot Eduardo Neves (1854-1899). 
"In a Negro dance I went to yesterday,

Where I saw a dark-skinned girl

So graceful was the child

That I didn't even know how to say

- How are you? I asked her

As soon as I saw her from close,

- Want to dance? I repeated,

My lovely one wasn't shy,

-tunda bobo, she told me,

Or better --- Get out of here...”

(In a Negro Dance by Eduardo Neves)

The common purpose of the nineteenth century Lusophone African poets were to discover the regional cultural history and identity, which was denied to them for centuries by the foreign rulers. It was perhaps for them the only non-violent path to overcome their self-alienation from the Negro society.

African poetry of the Lusophone countries offered right from its emergence, some realistic descriptions of their respective societies, in the process of celebrating its terra natal, and attempted to valorise the indigenous cultures as against the European one.

Nativisim brought rationalistic character in Lusophone African poetry giving predominance to ethno-cultural elements in its discourse. It was also successful in generating a consciousness of colour, the first manifestations of which can be detected in the works of José da Silva Maia Ferreira. The consciousness of being Black develops into a unifying force for the Negroes long exploited and oppressed by the White. Through the Black/White opposition, contextualised in poetry, the African poets evaluated and questioned for the first time the colonial equation -White=good, Black=bad.

The Portuguese politics of assimilation systematically instilled in the colonised so-called civilised values through centuries. The nineteenth century African poets writing in Portuguese could not liberate themselves completely from these colonial mindsets. This is evident in Maia Ferreira, Cordeiro da Matta and Caetano da Costa Alegre (1864-1890). Maia Ferreira attributed aristocratic value to the colour of the White while the colour of the Black to him was the opposite end of the spectrum, for him the black colour stood for everything base. In Cordeiro da Matta the White/Black opposition evidently exists, but the apologetic tone of Maia Ferreira is transformed in his case into a tone of acceptance. Thus Cordeiro da Matta unknowingly aggravated the problem of alienation which poets in general were trying to overcome contextualising it in contemporary literary discourse. In Negress, it is quite evident:

"Negress! Negress! like the night

Of a horrible tempest,

But, elegant, delicate and beautiful,

Like the most graceful beauty!

Negress! Negress! like the wing

Of the darkest and blackest raven,

But, having in the clear eyes,

The most limpid and pure look!”

(Negress by Cordeiro da Matta)

Costa Alegre though hailing from São Tomé e Principe, spent most of his short life in Portugal. In poetry his personal experience of being black is transformed into a collective experience; black and white exist as independent entities and not as terms of a binary opposition. Black, the colour of mourning, is associated with sufferings and sorrow whereas white is joy and happiness: 
Passes by an English lady

And soon blurts out

Very surprised:

"How black, my God!"

If it's a Spanish lady,

Who sees me,

She says like a bird:

"Que alto, Dios mio!"

And, if it's a French lady:

"O quel beau négre!"

Smiling at me

If it's a Portuguese lady,

Oh, Costa Alegre!

You have a sneeze!

(I and the Passer-by by Costa Alegre)

\section{CONCLUSION}

Thus the problematic of colour is present in African poems in Portuguese right from its inception. In reality, this consciousness of colour forged unity among the Blacks suffering through ages under the colonial rule. This is one basis for Africanity as expressed by Lusophone poets. They discovered their long denied culture and history through the use of ethno-cultural and topographical descriptions thus overcoming their age-long complete alienation from the indigenous society. While through nativism the African poets succeeded in creating regional consciousness, through Africanity the horizon of this consciousness was made wider and deeper too. Thus emerged the consciousness of a race among the Black peoples of this devastated continent.

Edward Said (1994) examines three topics of cultural resistance in the context of decolonization (i) insistence on the right to see the community's history as whole, coherently, integrally; (ii) the idea that resistance, far from being merely a reaction to imperialism, is an alternative way of conceiving human history; and (iii) a noticeable pull away from separatist nationalism towards a more integrative view of human community and human liberation. In this context, the role of the emergence of the literature in Portuguese produced by the African writers and the use of African ethno-cultural elements become relevant as part of resistance literature in the sense of literary autonomy.

\section{REFERENCE}

Ferreira, M. ( 1986). Literaturas Africanas de expressão Portuguesa. Lisboa : ICALP.

Mata, I. (1992).Pelos Trilhos da Literatura African em Língua Portuguesa Braga: Pontevedra.

Said, E.W. (1994). Culture and Imperialism. London: Vintage.

Sanyal, S. (1997). “The Rise of Nationalism in Lusophone African poetry with reference to similar tendencies in Indo-Portuguese literature” In African Literatures: Remembrances \& Constructions. Calcuta : Jadavpur University.

Venâncio, J.C. (1987). Uma Perspectiva Etnológica da Literatura Angolana.

Sacavém: Ulmeiro. 